\title{
Biocorona: The Shadowed Side of Nanoparticles
}

\author{
Fabiola Porta*, Daniel S Ehrsam and Henriette EU Meyer zu Schwabedissen \\ Department of Pharmaceutical Sciences, University of Basel, Switzerland
}

Submission: September 18, 2017; Published: September 22, 2017

*Corresponding author: Fabiola Porta, Department of Pharmaceutical Sciences, Group of Biopharmacy, University of Basel, Klingelbergstrasse 50-

70, 4056 CH, Switzerland, Email: Fabiola.porta@unibas.ch

\section{Abstract}

Under physiological conditions nanomaterials encounter a vast number of proteins in circulation. Those two dynamically interact with each other forming the so called biocorona. Accordingly, the biocorona is the layer of proteins in direct contact with the surface of nanomaterials, which may influence physical parameters of colloidal suspensions and thereby impact pharmacokinetics and dynamics of the formulated compound. Even though many experimental data have been gathered to understand the formation and the composition of the biocorona, the physiological impact of this protein layer is still a pristine area of research. The nature of the nanomaterials and the surface modifications performed to achieve controlled release of bioactive compounds influence thoroughly the nature of the biocorona. The focus of this review will be to evaluate how the protein-particles interactions influence the therapeutic outcome of nano formulated drugs.

Keywords: Nanoparticles; Biocorona; In vitro measurements; Pharmaceutical nanomaterials

\section{Introduction}

Particles with dimensions ranging from few to several hundred nanometers are defined as nanomaterials. Humankind has been always fascinated by nanosize materials as shown by the creation of special handcrafted objects during the Roman Empire with distinct features to change color depending of the light incidence such as the Lycurgus cup [1]. In the last decade impressive progress has been made in colloid synthesis [2] throughout the establishment of sol-gel techniques [3], mechanical alloying of metal [4] and molecular self-assembly [5], thereby significantly contributing to the flourishing field of nanomaterials. Indeed, the research focusing on potential fields of application of nanomaterials has not only reached industrial manufacturing of paints [6] and solar cells [7] but also various medical disciplines ranging from oncology [8] to cardiology [9]. Current applications of nanomaterials in medicine range from bioimaging [10] to nanoformulations [11]. Nanoformulations are nanosized pharmaceutical preparation of drug in the nanosized range [12]. Especially for nanomaterials used as nanocontainers of bioactive compounds [13-17], it is of fundamental importance to understand not only the intrinsic properties of the nanomaterial, but also the properties acquired once administered in vivo. The main goal of nanoformulations for oncological application is the prevention of severe side effects from the toxic compounds used in therapy [18]. However, the systemic administration of such nanocontainers has to be carefully investigated. One factor assumed to contribute to a change of material properties is the direct interaction with patient derived molecules. Accordingly, nanomaterials with potential application in life sciences need to be investigated considering these possible interactions with biological fluids which are characterized by a high content of proteins and salts [19]; molecular entities which are often not in the focus during synthesis and evaluation of nanomaterials. An excellent review of Del Pino and coworkers has described the protein adsorption onto nanoparticles using the Hill coefficient $\mathrm{n}$, together with a detailed mathematical description of protein adsorption phenomena [20].

The scope of this review is to describe a general method to tackle the identification and measurement of the protein-particle interactions and their physiological effects in case a therapeutic treatment is established with nanomaterials.

Due to the large surface area, nanosize biomaterials have high free energy which has the tendency to dynamically interact with molecular entities present in the surrounding [21]. Proteins are the major entity strongly interacts with the surface of nanoparticles. As soon as a nanomaterials is in contact with biological fluid, proteins are adsorbing on the surface forming a surrounding layer. The binding of this layer is assumed to be tight, however reversible, resulting in a dynamic exchange of proteins with the microenvironment. The protein layer, is also called biocorona, and is composed of a hard corona and a soft corona, characterized by a slow exchange and a fast exchange, respectively, of proteins. Interestingly it has been observed that among the 3,400 proteins of human plasma only a minor part of them is directly interacting with nanoparticles. However, these 
proteins lead to striking effects in terms of cellular uptake [2225]. For instance the adsorption of serum albumin on the surface of nanoparticles can lead to the perturbation of the protein structure depending on the surface charge of the nanomaterials [26]. This modification can drive the complex nanoparticlesprotein towards albumin receptors or scavenger receptor as demonstrated by Fleischer and collaborator [27]. Therefore, the "physiological coating" is the main part of the complex coming in contact with the cell and determining the consequent cellular uptake [28].

Protein adsorption has widely been studied in the field of biomedical nanoparticles [29]. However, Domkeand collaborators were the first investigating protein adsorption on the surface of biomedical materials via atomic force microscopy (AFM) [30]. Interestingly, adsorbed proteins can be "scratched" off using the sharp point of the microscope cantilever, thereby providing evidence that proteins interact with the material surface via weak interactions. This finding initiated the development of novel protein adsorption-resistant biomaterials [31,32]. In contrast to static techniques such as AFM, hydrodynamic investigations of the nanoparticle diameter can be conducted. Incubation with biological media are more realistic and describe the biocoronaprocesses better and in a more complex environment. This is due to the fact that the nanoparticles are still in contact with the biological fluid during measurement. For this reason, dynamic light scattering (DLS) [21], differential centrifugal sedimentation (DCS) [33] and fluorescence correlation spectroscopy (FCS) [34] are very well established techniques to describe the dynamic binding of proteins to nanoparticle surfaces. Throughout the DLS technique peaks referring to the diameter of the nanoformulations are reported during the analysis. Therefore, the interaction between nanoparticles and proteins is clearly visible as shift in diameter compared to the initial recorded dimensions $[29,35]$. Furthermore, DCS is the optimal technique to allow a real time evolution of the biocorona [33]; and using FCS investigation of the interaction protein-particle is feasible [34].

However, identification of the biocorona protein components is very challenging. As diverse as the material is, so are the affinities to various plasma proteins. Therefore, valuable identification method for the determination of the adsorbed protein is the analysis via LC-MS [25]. In addition, these biomolecules govern the fate of the nanocarriers upon administration in vivo. Biodistribution and cellular uptake and trafficking can be influenced by the biocorona [36]. In this case, opsonins, ie fibrinogen and complement factor, can promote macrophage uptake with consequent clearance of the nanocarriers from the circulation $[37,38]$. In contrast, di opsonins, i. e. human serum albumin and apolipoproteins, can increase blood circulation time [39].

Dynamicity of the biocorona is one peculiarity of this system. Monopoli and collaborators have investigated in detail how the adsorbed protein to the surface of nanomaterials change in time showing a progressive displacement of protein with lower affinity in favor of more affine proteins which are reaching the nanoparticle surface in a second time [21]. Moreover, the binding of more affine protein is significantly more stable allowing the formation of a compact protein coating with a stabilizing role for the formulation while lowering the free surface energy. It seems note worthy that the formation of a rapid coating of exogenous materials in the human organism significantly influences unwanted pathological effects such as coagulation, thrombosis or even cell death $[29,40]$.

\section{Conclusion}

The evaluation of the protein adsorption on the surface of nanoparticles is a phenomenon with significant importance. Several techniques have to be considered for a better understanding of the biocorona. In addition, as underlined by our review, nanoparticles for therapeutic application cannot be considered as isolated entities but as a continuum with the surrounding physiological medium. For this reason, the identification of the adsorbed proteins can be beneficial to allow a fine tuning of nanoparticles properties in order to achieve the desired therapeutic effects.

\section{Acknowledgement}

This work was supported by the grant Novartis Excellence Fellowship for Life Science, University of Basel.

\section{References}

1. Freestone I, Meeks M, Sax M, Higgitt C (2007) The Lycurgus Cup-A Roman nanotechnology. Gold Bull 40(4): 270-277.

2. Ghorbani HR (2014) A review of methods for synthesis of $\mathrm{Al}$ nanoparticles. Orient J Chem 30(4): 1941-1949.

3. Hench LL, West JK (1990) The sol-gel process. Chem Rev 90(1): 33-72.

4. El-Genk MS, Tournier JM (2005) A review of refractory metal alloys and mechanically alloyed-oxide dispersion strengthened steels for space nuclear power systems J Nucl Mater 340(1): 93-112.

5. Whitesides GM, Boncheva M. Beyond molecules: Self-assembly of mesoscopic and macroscopic components Proc Natl Acad Sci 99(8): 4769-4774.

6. Kaiser JP, Diener L, Wick P. Nanoparticles in paints: A new strategy to protect façades and surfaces? J Phys Conf Ser 429(1): 12036.

7. Tala-Ighil R (2016) Nanomaterials in solar cells. In: Tala-Ighil R (Ed.), Handbook of Nanoelectrochemistry. Springer International Publishing, Switzerland, pp. 1251-1270.

8. Porta F, Lamers GEM, Morrhayim J, Chatzopoulou A, Schaaf M, et al. (2013) Folic Acid-Modified Mesoporous Silica Nanoparticles for Cellular and Nuclear Targeted Drug Delivery Adv Healthc Mater 2(2): 281-286.

9. Gliesche DG, Hussner J, Witzigmann D, Porta F, Glatter T, et al. (2016) Secreted Matrix Metalloproteinase-9 of proliferating smooth muscle cells as a trigger for drug release from stent surface polymers in coronary arteries Mol Pharm 13(7): 2290-2300.

10. Hutter E, Maysinger D (2011) Gold nanoparticles and quantum dots for bioimaging. Microsc Res Tech 74(7): 592-604.

11. Kiene K, Porta F, Topacogullari B, Detampel P, Huwyler J (2017) Selfassembling chitosan hydrogel: A drug-delivery device enabling the sustained release of proteins. J Appl Polym Sci 135(1): 45638. 
12. Jeevanandam J, Chan YS, Danquah MK (2016) Nano-formulations of drugs: Recent developments, impact and challenges. Biochimie 128129: 99-112.

13. Riehemann K, Schneider SW, Luger TA, Godin B, Ferrari M, et al. (2009) Nanomedicine--challenge and perspectives., Angew Chem Int Ed Engl 48(5): 872-897.

14. Chauhan VP, Stylianopoulos T, Martin JD, Popović Z, Chen O, et al. (2012) Normalization of tumour blood vessels improves the delivery of nanomedicines in a size-dependent manner. Nat Nanotechnol 7(6): 383-388.

15. Minchin R (2008) Nanomedicine: Sizing up targets with nanoparticles. Nat Nanotechnol 3(1): 12-13.

16. Teli MK, Mutalik S, Rajanikant GK (2010) Nanotechnology and Nanomedicine: Going Small Means Aiming Big. Curr Pharm Des 16(16) 1882-1892.

17. Smita S, Gupta SK, Bartonova A, Dusinska M, Gutleb AC, et al. (2012) Nanoparticles in the environment: assessment using the causal diagram approach. Environ Health 11(Suppl 1): S13.

18. Torchilin VP (2005) Recent advances with liposomes as pharmaceutical carriers. Nat Rev Drug Discov 4(2): 145-160.

19. Rivera-Gil P, Jimenez DAD, Wulf V, Pelaz B, Pino DP, et al. (2013) The Challenge To Relate the Physicochemical Properties of Colloidal Nanoparticles to Their Cytotoxicity. Acc Chem Res 46(3): 743-749.

20. Pino DP, Pelaz B, Zhang Q, Maffre P, Nienhaus GU, et al. (2014) Protein corona formation around nanoparticles-from the past to the future. Mater Horiz 1(3): 301-313.

21. Monopoli MP, Walczyk D, Campbell A, Elia G, Lynch I, et al. (2011) Physical-chemical aspects of protein corona: relevance to in vitro and in vivo biological impacts of nanoparticles. J Am Chem Soc 133(8): 2525-2534.

22. Cedervall T, Lynch I, Lindman S, Berggård T, Thulin E, et al. (2007) Understanding the nanoparticle-protein corona using methods to quantify exchange rates and affinities of proteins for nanoparticles. Proc Natl Acad Sci U S A 104(7): 2050-2055.

23. Gref R, Lück M, Quellec P, Marchand M, Dellacherie E, et al. (2000) 'Stealth' corona-core nanoparticles surface modified by polyethylene glycol (PEG): Influences of the corona (PEG chain length and surface density) and of the core composition on phagocytic uptake and plasma protein adsorption. Colloids Surfaces B Biointerfaces 18(3-4): 301 313.

24. Mosqueira VCF, Legrand P, Gulik A, Bourdon O, Gref R, et al.(2001) Relationship between complement activation, cellular uptake and surface physicochemical aspects of novel PEG-modified nanocapsules. Biomaterials 22(22): 2967-2979.

25. Lundqvist M, Stigler J, Cedervall T, Berggård T, Flanagan MB, et al. (2011) The evolution of the protein corona around nanoparticles: a test study. ACS Nano 5(9): 7503-7509.

26. Silin VV, Weetall H, Vanderah DJ (1997) SPR Studies of the Nonspecific Adsorption Kinetics of Human IgG and BSA on Gold Surfaces Modified by Self-Assembled Monolayers (SAMs). J Colloid Interface Sci 185(1): 94-103.

27. Fleischer CC, Payne CK (2014) Nanoparticle-cell interactions: molecular structure of the protein corona and cellular outcomes. Acc Chem Res 47(8): 2651-2659.

28. Tenzer S, Docter D, Kuharev J, Musyanovych A, Fetz V, et al. (2013) Rapid formation of plasma protein corona critically affects nanoparticle pathophysiology. Nat Nanotechnol 8(10): 772-781.

29. Monopoli MP, Åberg C, Salvati A, Dawson KA (2012) Biomolecular coronas provide the biological identity of nanosized materials. Nat Nanotechnol 7(12): 779-786.

30. Domke J, Dannöhl S, Parak WJ, Müller O, Aicher WK, et al. (2000) Substrate dependent differences in morphology and elasticity of living osteoblasts investigated by atomic force microscopy. Colloids Surf B Biointerfaces 19(4): 367-379.

31. Amirgoulova EV, Groll J, Heyes CD, Ameringer T, Röcker C, et al. (2004) Biofunctionalized Polymer Surfaces Exhibiting Minimal Interaction towards Immobilized Proteins. ChemPhysChem 5(4): 552-555.

32. Mrksich M, Whitesides GM (1996) Using Self-Assembled Monolayers to Understand the Interactions of Man-made Surfaces with Proteins and Cells. Annu Rev Biophys Biomol Struct 25(1): 55-78.

33. Lees EE, Gunzburg MJ, Nguyen TL, Howlett GJ, Rothacker J, et al. (2008) Experimental Determination of Quantum Dot Size Distributions, Ligand Packing Densities, and Bioconjugation Using Analytical Ultracentrifugation. Nano Lett 8(9): 2883-2890.

34. Liedl T, Keller S, Simmel FC, Rädler JO, Parak WJ (2005) Fluorescent Nanocrystals as Colloidal Probes in Complex Fluids Measured by Fluorescence Correlation Spectroscopy. Small 1(10): 997-1003.

35. Abdelmohsen LKEA, Rikken RSM, Christianen PCM, van Hest JCM, Wilson DA (2016) Shape characterization of polymersome morphologies via light scattering techniques. Polymer 107: 445-449.

36. Fuchs SM, Raines RT (2004) Pathway for Polyarginine Entry into Mammalian Cells. Biochemistry 43(9): 2438-2444.

37. Sandgren S, Wittrup A, Cheng F, Jönsson M, Eklund E, et al. (2004) The human antimicrobial peptide LL-37 transfers extracellular DNA plasmid to the nuclear compartment of mammalian cells via lipid rafts and proteoglycan-dependent endocytosis. J Biol Chem 279(17): 17951-17956.

38. Mislick KA, Baldeschwieler JD (1996) Evidence for the role of proteoglycans in cation-mediated gene transfer. Proc Natl Acad Sci U S A 93(22): 12349-12354.

39. Mounkes LC, Zhong W, Palacin GC, Heath TD, Debs RJ (1998) Proteoglycans mediate cationic liposome-DNA complex-based gene delivery in vitro and in vivo. J Biol Chem 273(40): 26164 26170.

40. Dobrovolskaia MA, Clogston JD, Neun BW, Hall JB, Patri AK, et al. (2008) Method for Analysis of Nanoparticle Hemolytic Properties in vitro. Nano Lett 8(8): 2180-2187. 
This work is licensed under Creative Commons Attribution 4.0 Licens DOI: 10.19080/MABB.2017.02.555586

\section{Your next submission with Juniper Publishers will reach you the below assets}

- Quality Editorial service

- Swift Peer Review

- Reprints availability

- E-prints Service

- Manuscript Podcast for convenient understanding

- Global attainment for your research

- Manuscript accessibility in different formats ( Pdf, E-pub, Full Text, Audio)

- Unceasing customer service

Track the below URL for one-step submission https://juniperpublishers.com/online-submission.php 